\title{
The Effect of Organizational Culture, Organizational Justice, and Organizational Commitment on Organizational Citizenship Behavior (OCB)
}

\author{
Sri Winarsih, Setyo Riyanto
}

\begin{abstract}
Organizational citizenship behavior (OCB), which is known as extra-role behavior, is an important factor for the organization to maintain the survival and achievement of organizational goals. OCB is very effective to be applied in human resource management because it can direct employees to provide performance that is more than just carrying out their formal duties. This study aimed to determine the influence of organizational culture, organizational justice, and organizational commitment to employee OCB at a vocational high school in the South Tangerang area, Indonesia. The research was quantitative study with a population of all school employees as many as 70 people. The sampling technique used nonpropability sampling, namely saturated samples. Data analysis was performed using a simple correlation analysis method and multiple linear regression with the help of IBM SPSS version 23. The results showed that organizational culture, organizational justice, and organizational commitment had a positive and significant effect on OCB either partially or simultaneously.
\end{abstract}

Keywords: Organizational Culture, Organizational Justice, Organizational Commitment, Organizational Citizenship Behavior

\section{INTRODUCTION}

$\mathrm{T}$

he success of an organization in achieving its vision and mission is largely determined by the quality of its human resources. Batugal \& Tindowen (2019) stated that human resources are the driving force of an organization, and managing their capabilities will contribute a lot in realizing the quality and productivity of the organization. As one of the important assets in an organization, human resources need to receive more attention from the organization because the sustainability and achievement of organizational goals do not only depend on material or technological developments but also depends on the existence of these human resources (Puspitasari, 2020). The ability of an organization to compete

Revised Manuscript Received on September 13, 2020.

* Correspondence Author

Sri winarsih*, Post Graduate Student, Universitas Mercu Buana, Jakarta, Indonesia. Email: wienarsih27@gmail.com.

Setyo Riyanto, Post Graduate Lecturer, Universitas Mercu Buana, Jakarta, Indonesia. Email: setyo.riyanto@mercubuana.ac.id

(C) The Authors. Published by Blue Eyes Intelligence Engineering and Sciences Publication (BEIESP). This is an open access article under the CC BY-NC-ND license (http://creativecommons.org/licenses/by-nc-nd/4.0/) in the global market results from a combination of strategy and competent management practices with the quality of human resources and the activeness of the employees themselves (Darius \& Wojtczuk, 2015). However, the quality of employees in an organization cannot only be seen from how many employees can contribute and complete all their tasks properly, but it can be seen from the number of employees who have their initiative in completing other work outside their job description (Nawangsari \& Prasetya, 2019). In other research, Nawangsari \& Sutawidjaya (2018) argued that to get optimal organizational performance, management expects employee performance to exceed expectations, employees need to do work that is more than their usual duties. Darius \& Wojtczuk (2015) also stated that overall organizational performance could be traced from OCB behavior. Schools, as a formal educational institution, also really need quality human resources to provide optimal educational services. Personality competence, which can be seen from the maturity of attitude and high work ethic, is a reflection of OCB as one of the competencies that must be mastered by all school employees. The pre-research done at a private vocational school in the South Tangerang area indicated that the percentage of employees who did not have OCB behavior was still quite high. This pre-research was conducted by distributing questionnaires to 30 employees who had a service period of more than three years. The pre-research results can be seen in table (1).

Table (1): The Result of Organizational Citizenship Behavior Pre-Research

\begin{tabular}{|c|c|c|}
\hline Statement & Yes & No \\
\hline $\begin{array}{l}\text { I always help colleagues who have a high } \\
\text { workload. }\end{array}$ & 76.67 & 23.33 \\
\hline $\begin{array}{l}\text { I am willing to give more time to do school } \\
\text { assignments. }\end{array}$ & 70.00 & 30.00 \\
\hline $\begin{array}{l}\text { I have never complained (complain) about trivial } \\
\text { things outside of my job. }\end{array}$ & 66.67 & 33.33 \\
\hline $\begin{array}{l}\text { I always know all the information about } \\
\text { developments and changes that occur in school. }\end{array}$ & 86.67 & 13.33 \\
\hline $\begin{array}{l}\text { In completing work, I always think about how my } \\
\text { actions will impact my co-workers. }\end{array}$ & 90.00 & 10.00 \\
\hline Average & 78.00 & 22.00 \\
\hline
\end{tabular}

Published By:

Blue Eyes Intelligence Engineering

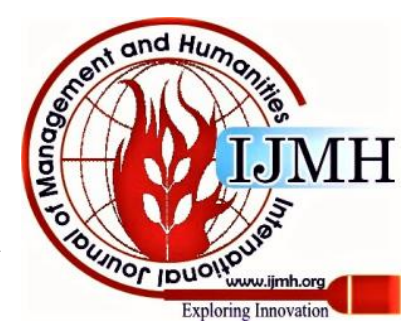




\section{The Effect of Organizational Culture, Organizational Justice, and Organizational Commitment on Organizational Citizenship Behavior (OCB)}

It shows that there are still $23.33 \%$ of employees who do not always help colleagues who have a high workload, $30.00 \%$ of employees who are not willing to give more time to do school assignments, and $33.33 \%$ of employees who complain about trifles beyond his duties. The formation of OCB behavior in an employee is influenced by various factors.

To find out what factors were dominant in influencing the formation of OCB at this school, the author distributed questionnaires covering the scope of organizational culture, work climate, perceptions of organizational support, job satisfaction, organizational justice, organizational commitment, and work motivation. The results of pre-research for these factors can be seen in figure (1), which shows that the three research variables, namely organizational culture, organizational justice, and organizational commitment, have a high average no answer, respectively $17.33 \%, 17.33 \%$, and $20.67 \%$.

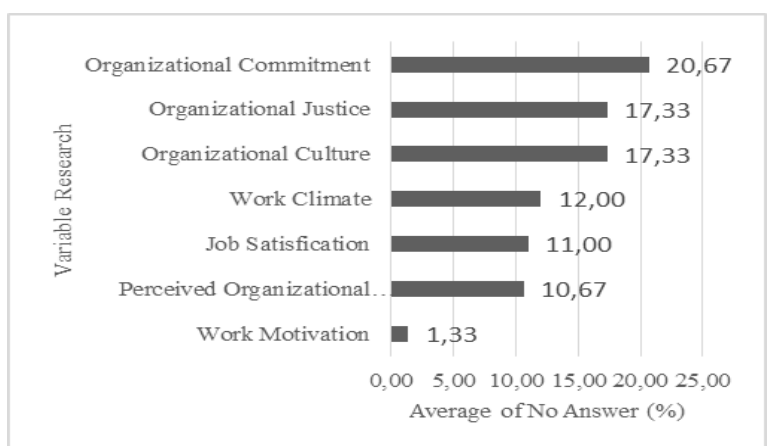

Figure (1): The Result of Variable Pre-Research

Several previous studies stated that organizational culture, organizational justice, and organizational commitment influence Organization Citizenship Behavior (OCB). Maysarah \& Rahardjo (2015) and Desselle et al. (2015) found out that organizational culture affects OCB. Indahyati \& Sintaasih (2019) stated that distributive justice, procedural justice, and interactional justice have a positive effect and did not have a significant impact on OCB. This result is in contrast to the findings by Awang \& Ahmad (2017) that distributive justice and interactional justice have a significant relationship and influence on OCB. In their research, Taghinezhad et al. (2015) found out that procedural justice has a significant effect on OCB. Khaleh \& Naji (2016) stated that normative commitment has a positive and significant relationship with OCB, while affective commitment and continuation commitment have no significant effect on OCB. Therefore, the author needs to conduct a study entitled "The Effect of Organizational Culture, Organizational Justice, and Organizational Commitment on Organizational Citizenship Behavior (OCB)."

\section{LITERATURE REVIEW}

\section{Organizational Culture}

Organizational culture is a set of values, norms, beliefs, and understandings that are shared with all members of the organization and taught to new members as the correct way to think, feel and behave (Daft, 2016: 386). Robbins \& Judge (2017: 355) stated that organizational culture refers to a system of sharing meaning carried out by members that differentiate an organization from other organizations, and strong organizational culture will provide stability to the organization and have a significant influence on the behavior of the members of the organization. Bakti (2020) declared that organizational culture has a significant influence on employee performance. There are four dimensions in organizational culture, namely: clan culture, mission culture, adaptability culture, bureaucratic culture (Daft, 2016: 393).

\section{Organizational Justice}

Robbins \& Judge (2017: 143-145) argued that the theory of justice is a theory that states individual comparisons of the input and results of their work and responds to eliminate injustice. Organizational fairness focuses more broadly on how workers feel the authority and decision-makers at work in treating them. The impact of organizational justice, according to Mishra and Mishra (1994) in Yean \& Yosuf (2015), is: building trust, building OCB behavior, improving organizational performance. The dimensions of organizational justice include distributive justice, procedural justice, interactional justice (Robbins \& Judge, 2017: 145).

\section{Organizational Commitment}

Organizational commitment is related to the extent to which people are involved in their organization and are interested in staying in it (Greenberg, 2011: 771). Naiemah et al. (2017) stated that having committed employees is a bonus for the organization because it will help the organization to transmit its quality to company productivity. Employees who have high commitment will carry out their duties optimally and produce high performance. Sani \& Soetjipto (2016), in their research on a banking organization, found that employee organizational commitment is an important aspect in determining the success of banking reform and banking effectiveness because highly committed employees are willing to contribute in their extra efforts to achieve the banking vision and goals. Regarding turn over the intention, Santoso (2020) argued that organizational commitment, namely normative commitment, has a significant and negative effect, which means the higher the normative commitment, the lower the employee's desire to leave the organization. According to Greenberg (2011: 231), there are three dimensions of organizational commitment, namely: affective commitment, continuation commitment, and normative commitment.

\section{Organizational Citizenship Behavior (OCB)}

Organs in Demirel et al. (2018) defined that OCB is an individual voluntary behavior outside the scope of functional duties and is not related to direct relationships and community relations with the formal reward system. Podsakoff in Veličkovska (2017) determined 30 different types of OCB and divided them into seven dimensions, namely: helpful behavior, sportsmanship, organizational loyalty, organizational compliance, individual initiative, civic virtue, individual development. Organ in Demirel et al. (2018) suggested five main dimensions of OCB, namely: altruism, civic virtue, conscientiousness, courtesy, sportsmanship. These dimensions reflect organizational behavior such as helping colleagues, following organizational rules and procedures, and not complaining and participating actively in organizational activities.

Published By:

Blue Eyes Intelligence Engineering

\& Sciences Publication

(C) Copyright: All rights reserved.

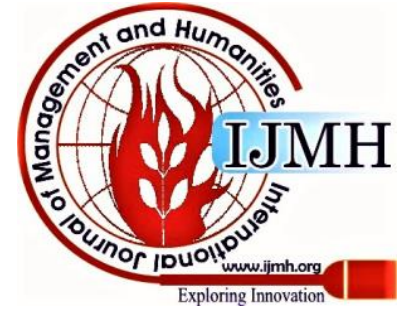


Organ (1988) in Kumari \& Thapliyal (2017) considered OCB as an vital factor for the survival and effectiveness of an organization.

OCB is also essential in educational organizations. School managers must know how to foster teacher's OCB attitudes because teaching is a complex activity, often demands to be done outside of working hours, and all these behaviors or activities can hardly be fully regulated in the teacher's work contract (Junru, 2019). According to Cheasakul \& Varma (2016), teachers play a very significant role in student life and school success. Teachers who have an OCB will provide extra time for schools and students voluntarily.

Demirel et al. (2018), argued that the most important organizational factors that influence OCB are organizational justice, commitment to an organization, job satisfaction, organizational culture, and managerial style. Ghashghaeinia \& Hafezi (2015) and Setyaningrum (2017) found that organizational culture has a positive and significant influence on OCB. According to Kittikunchotiwut (2017), organizational justice is one of the main components that affect OCB. Tran (2019), stated that organizational justice and learning culture have a positive effect on OCB. Pan et al. (2019) stated that procedural justice contributed a much more significant variance than distributive justice in positive employee behavior. Chib S. (2016) claimed that organizational commitment is a predictor for OCB, which has a significant influence, in addition to work environment factors, job satisfaction, organizational justice, and loyalty. Musringudin (2016), in his research on educational organizations, argued that organizational justice and organizational commitment have a positive effect on the OCB of school principals. Imamoglu, S.Z. et al. (2019) also stated that organizational justice and organizational commitment determine employee attitudes to be useful for the organization, do things that are beneficial to the organization, and work seriously. Nugraha \& Adnyani (2018) found that organizational culture and organizational commitment have positive and significant effect on OCB simultaneously.

\section{A. The Research Framework}

The research framework created, as shown in figure (2), is a simple model for investigating the influence of independent variables on the dependent variable.

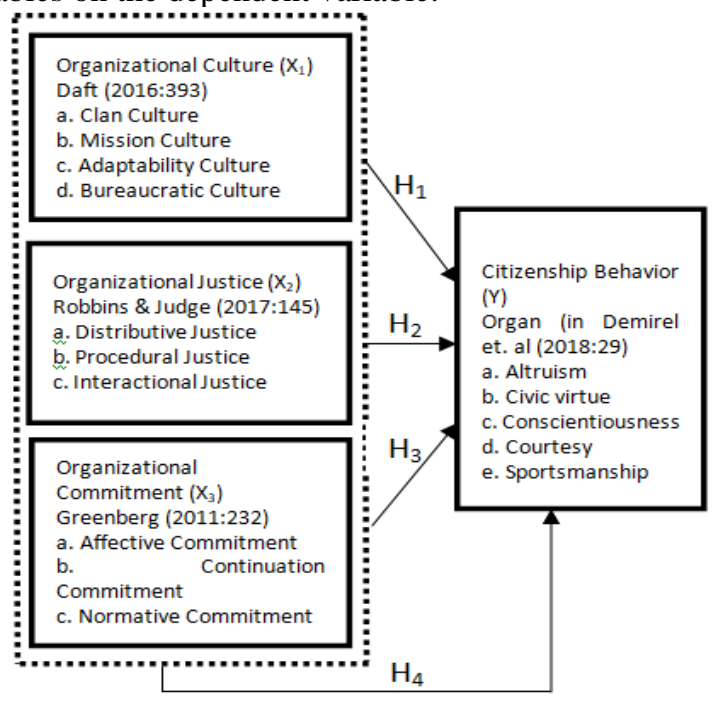

Figure (2): The Research Framework

\section{Hypothesis}

H1: Organizational culture affects organizational citizenship behavior.

H2: Organizational justice affects organizational citizenship behavior.

$\mathbf{H}_{3}$ : Organizational commitment affects organizational citizenship behavior.

$\mathbf{H}_{4}$ : Organizational culture, organizational justice, and organizational commitment simultaneously affect organizational citizenship behavior.

\section{RESEARCH METHODS}

This research was a quantitative study with a cross-sectional design in which data collection from a particular sample was only done once and at a time. This research was causality, which tested whether or not a variable influenced changes in other variables. This study was conducted to test the concepts in the hypothesis about the influence of organizational culture, organizational justice, and organizational commitment to OCB. The population in this study amounted to 70 people, consisting of teachers, administrative staff, and support staff. The sampling technique used was nonprobability sampling in the form of a saturated sample, in which all members of the population became the research sample. Primary data was collected by giving questions or statements in writing to respondents in the form of a questionnaire with a Likert scale of $1-5$. The Likert scale had five degrees of an answer, namely 1 (strong disagree), 2 (disagree), 3 (neutral), 4 (agree), and 5 (strongly agree). Data analysis was performed using a simple correlation analysis method and multiple linear regression with the help of IBM SPSS (Statistical Product and Service Solution) version 23.

\section{RESULT AND DISCUSSION}

Validity Test - The validity test was performed using the Pearson correlation method. This test used a confidence level of $95 \%$ and a significance level of $5 \%$. The number of respondents was 70 , so the value of $\mathrm{df}=68$ was obtained, then the value of $r$ table $=0.235$. Based on the data (table 2), it can be stated that all question items in the questionnaire are declared valid because $r$ count $>r$ table.

Table (2): The Result of Validity Test

\begin{tabular}{|l|c|c|c|c|}
\hline \multicolumn{1}{|c|}{$\begin{array}{c}\text { Research } \\
\text { Variable }\end{array}$} & $\begin{array}{c}\mathrm{N} \text { of } \\
\text { Items }\end{array}$ & $\begin{array}{c}\text { Range of } \mathrm{r} \\
\text { count Value }\end{array}$ & $\begin{array}{c}\mathrm{r}_{\text {table }} \\
\text { Value }\end{array}$ & Notes \\
\hline $\begin{array}{l}\text { Organizational } \\
\text { Culture }\end{array}$ & 25 & $0.670-0.920$ & 0.235 & Valid \\
\hline $\begin{array}{l}\text { Organizational } \\
\text { Justice }\end{array}$ & 16 & $0.783-0.907$ & 0.235 & Valid \\
\hline $\begin{array}{l}\text { Organizational } \\
\text { Commitment }\end{array}$ & 14 & $0.665-0.875$ & 0.235 & Valid \\
\hline $\begin{array}{l}\text { Organizational } \\
\text { Citizenship } \\
\text { Behaviour }\end{array}$ & 20 & $0.498-0.790$ & 0.235 & Valid \\
\hline
\end{tabular}

Reliability Test - The reliability test was carried out using the Cronbach Alpha correlation formula.

Published By:

Blue Eyes Intelligence Engineering

\& Sciences Publication

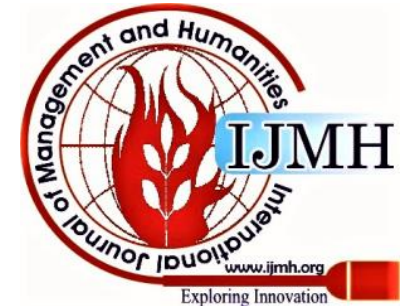


Based on the test results, table (3), all instruments in this study have a Cronbach Alpha value $>0.60$. It can be concluded that all research variables are reliable to be used as research instruments.

Table (3): The Result of Reliability Test

\begin{tabular}{|l|c|c|c|}
\hline \multicolumn{1}{|c|}{ Research Variable } & $\begin{array}{c}\text { Cronbach's } \\
\text { Alpha }\end{array}$ & $\begin{array}{c}\text { N of } \\
\text { Items }\end{array}$ & $\begin{array}{c}\text { Standard } \\
\text { Value }\end{array}$ \\
\hline Organizational Culture $\left(\mathrm{X}_{1}\right)$ & 0.984 & 25 & 0.60 \\
\hline Organizational Justice $\left(\mathrm{X}_{2}\right)$ & 0.974 & 16 & 0.60 \\
\hline $\begin{array}{l}\text { Organizational Commitment } \\
\left(\mathrm{X}_{3}\right)\end{array}$ & 0.949 & 14 & 0.60 \\
\hline $\begin{array}{l}\text { Organizational Citizenship } \\
\text { Behaviour }(\mathrm{Y})\end{array}$ & 0.927 & 20 & 0.60 \\
\hline
\end{tabular}

Normality Test - The normality test aimed to find out whether the data were normally distributed or not by using the Kolmogorov-Smirnov One-Sample test. Based on the data in table (4), it can be concluded that the data are normally distributed due to the asymmetry value. Sig $=0.065$ that meets the requirements, namely the value of asyimp. $\mathrm{S}>$ 0.05 .

Table (4): The Result of Normality Test

\begin{tabular}{|ll|r|}
\hline & & \multicolumn{2}{|c|}{$\begin{array}{c}\text { Unstandardized } \\
\text { Residual }\end{array}$} \\
\hline $\mathrm{N}$ & & 70 \\
Normal Parameters ${ }^{\mathrm{a}, \mathrm{b}}$ & Mean & .0000000 \\
& Std. Deviation & .45904888 \\
Most Extreme & Absolute & .103 \\
Differences & Positive & .103 \\
& Negative & -.101 \\
Test Statistic & & .103 \\
Asymp. Sig. (2-tailed) & & $.065^{\mathrm{c}}$ \\
\hline
\end{tabular}

The normality test can also be determined based on the distribution of data on the p-p plots graph (figure 3) and the normal curves are formed (figure 4). Figure (3) shows that the residual data spread around the line and follows the direction of the diagonal line indicates that the residue in the regression model has a normally distributed distribution.

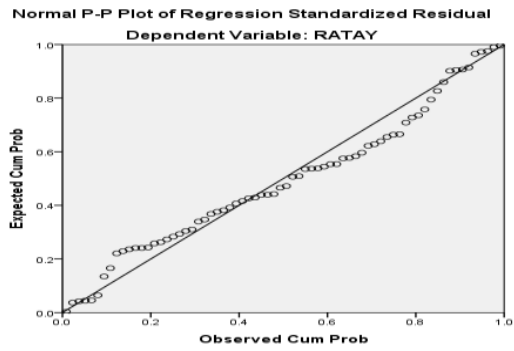

Figure (3): The p - p Plot Graph

The histogram graph (figure 4) shows that the curves formed are normal curves, where the average area to the right and left is close to $50 \%$ each.

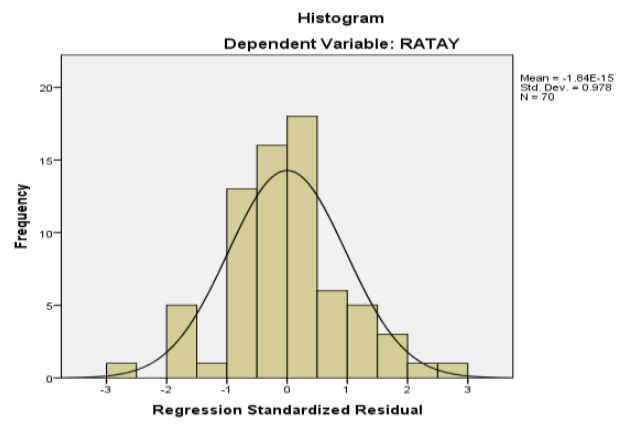

Figure (4): The Histogram Graph
Multicollinearity Test - Assessment of multicollinearity tests was determined based on the value of tolerance and VIF (Variance Inflated Factor). The results of the multicollinearity test are presented in table 5 . It shows that the tolerance value of each independent variable $>0.1$ and the VIF value of each independent variable $<10$, it can be concluded that the regression model in this study is free from multicollinearity between the independent variables.

Table (5): The Result of Multicollinearity Test

\begin{tabular}{|l|l|c|l|}
\hline \multicolumn{1}{|c|}{$\begin{array}{c}\text { Independent } \\
\text { Variable }\end{array}$} & $\begin{array}{c}\text { Toleranc } \\
\text { e Value }\end{array}$ & $\begin{array}{c}\text { Value } \\
\text { of VIF }\end{array}$ & \multicolumn{1}{|c|}{ Notes } \\
\hline $\begin{array}{l}\text { Organizational } \\
\text { Culture }\left(\mathrm{X}_{1}\right)\end{array}$ & 0.487 & 2.055 & $\begin{array}{l}\text { Non } \\
\text { Multicollinearity }\end{array}$ \\
\hline $\begin{array}{l}\text { Organizational } \\
\text { Justice }\left(\mathrm{X}_{2}\right)\end{array}$ & 0.531 & 1.885 & $\begin{array}{l}\text { Non } \\
\text { Multicollinearity }\end{array}$ \\
\hline $\begin{array}{l}\text { Organizational } \\
\text { Commitment }\left(\mathrm{X}_{3}\right)\end{array}$ & 0.508 & 1.967 & $\begin{array}{l}\text { Non } \\
\text { Multicollinearity }\end{array}$ \\
\hline
\end{tabular}

Heteroscedasticity Test - Heteroscedasticity test was carried out using the Glejser test, provided that the Sig. value of the independent variable $>0.05$, then all the independent variables did not have symptoms of heteroscedasticity in the residual data or other words were homoscedasticity. The results of the heteroscedasticity test (table 6) show that the Sig. each independent variable $>0.05$. It can be said that all independent variables do not have symptoms of heteroscedasticity.

Table (6): The Result of Heteroscedasticity Test

\begin{tabular}{|l|c|c|}
\hline \multicolumn{1}{|c|}{ Independent Variable } & Value of Sig. & Notes \\
\hline $\begin{array}{l}\text { Organizational Culture } \\
\left(\mathrm{X}_{1}\right)\end{array}$ & 0.096 & Non-heteroscedasticity \\
\hline $\begin{array}{l}\text { Organizational Justice } \\
\left(\mathrm{X}_{2}\right)\end{array}$ & 0.500 & Non-heteroscedasticity \\
\hline $\begin{array}{l}\text { Organizational } \\
\text { Commitment }\left(\mathrm{X}_{3}\right)\end{array}$ & 0.313 & \\
\hline
\end{tabular}

This is also made clear by the residual plot graph (figure 5). Data distribution graphs form unclear patterns and points spread above and below the number 0 on the $\mathrm{Y}$-axis. This graph indicates that residuals have the same variant (homoscedasticity).

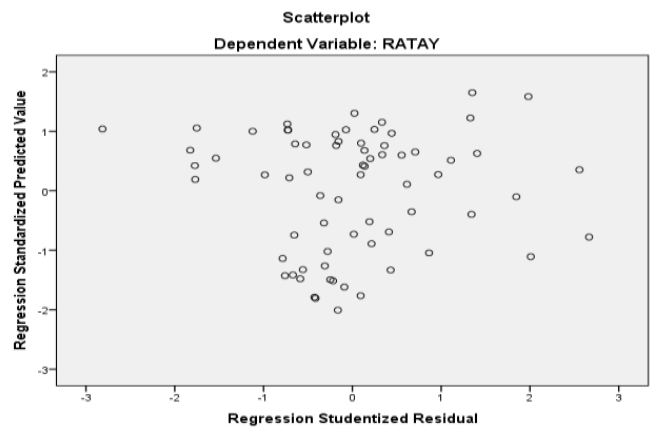

Figure (5): Data Distribution Graph

Multiple Linear Regression Analysis - Regression models were used to predict the value of the dependent variable if the independent variable changed (increased or decreased) and also to determine the direction of the relationship between the two variables, whether positive or negative.

Published By:

Blue Eyes Intelligence Engineering

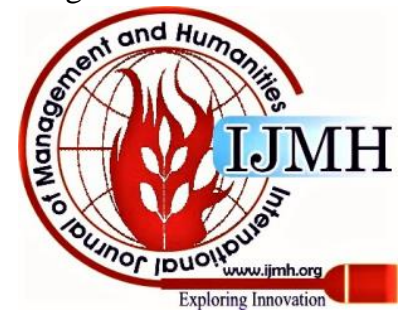


In this study, there was more than one independent variable, so the regression model used was multiple linear regression. The results of multiple linear regression analyses are shown in table (7).

\section{Table (7): The Result of Multiple Linear Regression} Analysis

\begin{tabular}{|c|c|c|c|c|c|c|c|}
\hline \multirow[b]{2}{*}{ Model } & \multicolumn{2}{|c|}{$\begin{array}{l}\text { Unstandardized } \\
\text { Coefficients }\end{array}$} & \multirow{2}{*}{$\begin{array}{c}\text { Standar } \\
\text { dized } \\
\text { Coeffic } \\
\text { ients } \\
\text { Beta }\end{array}$} & \multirow[b]{2}{*}{$\mathrm{t}$} & \multirow[b]{2}{*}{ Sig. } & \multicolumn{2}{|c|}{$\begin{array}{l}\text { Collinearity } \\
\text { Statistics }\end{array}$} \\
\hline & B & $\begin{array}{l}\text { Std. } \\
\text { Error }\end{array}$ & & & & Tolerance & VIF \\
\hline $\begin{array}{ll}1 & \text { (Con } \\
& \text { stant) }\end{array}$ & 1.084 & .233 & & 4.659 & .000 & & \\
\hline $\mathrm{X} 1$ & .237 & .069 & .381 & 3.422 & .001 & .487 & $\begin{array}{r}2.0 \\
55\end{array}$ \\
\hline $\mathrm{X} 2$ & .155 & .071 & .234 & 2.189 & .032 & .531 & $\begin{array}{r}1.8 \\
85\end{array}$ \\
\hline X3 & .220 & .087 & .274 & 2.510 & .015 & .508 & $\begin{array}{r}1.9 \\
67\end{array}$ \\
\hline
\end{tabular}

The regression equation is as follows:

$$
\mathrm{Y}=1,084+0,237 \mathrm{X} 1+0,155 \mathrm{X} 2+0,220 \mathrm{X} 3+\mathrm{e}
$$

From the regression equation, it can be explained that a constant of 1.084 means that the OCB will be worth 1,084 if the organizational culture, organizational justice, and organizational commitment have a coefficient of 0 . Based on an assessment with a Likert scale where the value of 1 strongly disagrees, the constant value of 1.084 illustrates that the employee's OCB condition is not very good. Organizational culture variables, organizational justice, and organizational commitment have coefficients that are positive for OCB employees. The coefficient of organizational culture is 0.237 which means that if the culture of the organization has increased by one unit, the OCB will increase by 0.237 assuming the value of the other variables is fixed. Likewise, the variables of organizational justice and organizational commitment. OCB will increase by 0.155 if organizational justice is increased by one unit and OCB will increase by 0.220 if the organizational commitment is increased by one unit.

Determination Coefficient Test $\left(\mathbf{R}^{2}\right)$ - The coefficient of determination test was used to assign the level of contribution made by the independent variable to the value of the dependent variable. Based on the data (table 8), the R2 value is 0.602 , which means that the variables of organizational culture, organizational justice, and organizational commitment contribute $60.2 \%$ to the organizational citizenship behavior variable, while the remaining 39.8\% can be explained by other variables.

Table (8): The Result of Determination Coefficient Test

\begin{tabular}{|l|c|r|r|r|r|}
\hline Model & $\mathrm{R}$ & R Square & $\begin{array}{c}\text { Adjusted R } \\
\text { Square }\end{array}$ & $\begin{array}{c}\text { Std. Error } \\
\text { of the } \\
\text { Estimate }\end{array}$ & $\begin{array}{c}\text { Durbin- } \\
\text { Watson }\end{array}$ \\
\hline 1 & $0.776^{\mathrm{a}}$ & 0.602 & 0.584 & 0.46937 & 2.121 \\
\hline
\end{tabular}

Simultaneous Test (F) - Simultaneous test was used to determine whether the independent variables in the regression model had a joint influence on the dependent variable. Table (9), the simultaneous test results, show that the value of $\mathrm{F}$ count $=33.225$ with the value of Sig. $=0,000$. Following the basis of decision making in the F-test decision, that the value of Sig. <alpha value $5 \%$, it can be stated that there is a significant and simultaneous influence between the three variables, organizational culture, organizational justice, and organizational commitment, on organizational citizenship behavior.

Table (9): The Result of Simultaneous Test

\begin{tabular}{|c|c|c|c|c|c|}
\hline Model & $\begin{array}{c}\text { Sum of } \\
\text { Squares }\end{array}$ & df & $\begin{array}{l}\text { Mean } \\
\text { Square }\end{array}$ & $\mathrm{F}$ & Sig. \\
\hline 1 Regression & 21.959 & 3 & 7.320 & 33.225 & $.000^{b}$ \\
\hline Residual & 14.540 & 66 & 0.220 & & \\
\hline Total & 36.499 & 69 & & & \\
\hline
\end{tabular}

Partial Test (t) - Partial test was used to determine the level of influence of each independent variable on the dependent variable. The data (Table 10) obtained shows that the organizational culture variable has a value of $t$ count $>t$ table $(3,422>1,668)$ and value of Sig. $(=0.001)<0.05$, which means that Ho is rejected and Ha is accepted, so it can be stated that partially organizational culture has a significant influence on OCB. The organizational justice variable has a value of t count $>\mathrm{t}$ table $(2.189>1.668)$ and value of Sig. (= $0.032)<0.05$, which means that Ho is rejected and Ha is accepted, so it can be stated that partially organizational justice has a significant effect on OCB. The variable of organizational commitment has a value of $t$ count $>t$ table $(2.510>1.668)$ and value of Sig. $(=0.015)<0.05$. which means that Ho is rejected and Ha is accepted, so it can be stated that partially organizational commitment has a significant influence on OCB.

Table (10): The Result of Partial Test

\begin{tabular}{|c|c|c|c|c|c|c|c|}
\hline \multirow[b]{2}{*}{ Model } & \multicolumn{2}{|c|}{$\begin{array}{l}\text { Unstandardi } \\
\text { zed } \\
\text { Coefficients }\end{array}$} & \multirow{2}{*}{$\begin{array}{c}\text { Standar } \\
\text { dized } \\
\text { Coeffic } \\
\text { ients } \\
\\
\text { Beta }\end{array}$} & \multirow[b]{2}{*}{$\mathrm{t}$} & \multirow[b]{2}{*}{ Sig. } & \multicolumn{2}{|c|}{$\begin{array}{c}\text { Collinearity } \\
\text { Statistics }\end{array}$} \\
\hline & B & $\begin{array}{l}\text { Std. } \\
\text { Error }\end{array}$ & & & & $\begin{array}{c}\text { Tolera } \\
\text { nce }\end{array}$ & VIF \\
\hline $\begin{array}{l}1 \text { (Consta } \\
\text { nt) }\end{array}$ & 1.084 & .233 & & 4.659 & .000 & & \\
\hline $\mathrm{X} 1$ & .237 & .069 & .381 & 3.422 & .001 & .487 & 2.055 \\
\hline $\mathrm{X} 2$ & .155 & .071 & .234 & 2.189 & .032 & .531 & 1.885 \\
\hline X3 & .220 & .087 & .274 & 2.510 & .015 & .508 & 1.967 \\
\hline
\end{tabular}

Inter-Dimensional Correlation Analysis (r test) Correlation test was performed using Pearson's two-tailed correlation method, which aimed to determine the magnitude of the relationship between the dimensions of each independent variable and the dimensions of the dependent variable. The level of relationship between the dimensions of the independent variable and the dimensions of the dependent variable can be determined based on standard coefficient intervals with references: very weak (0.00 - 0.19), weak (0.20 $0.399)$, moderate $(0.40-0.599)$, strong (0.60 - 0.799), and very strong $(0.80$ - 1.00).

ciences Publication

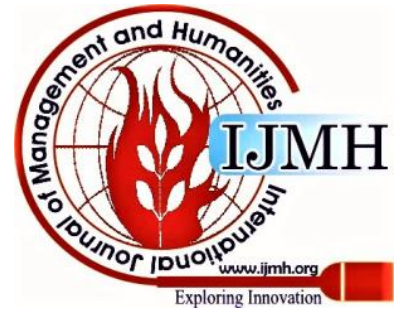


The Effect of Organizational Culture, Organizational Justice, and Organizational Commitment on Organizational Citizenship Behavior (OCB)

Table 11: The Result of Dimensional Correlation Analysis

\begin{tabular}{|c|c|c|c|c|c|}
\hline \multirow[b]{2}{*}{ Dimension } & \multicolumn{5}{|c|}{ Organizational Citizenship Behavior } \\
\hline & Altruism & $\begin{array}{l}\text { Civic } \\
\text { Virtue }\end{array}$ & Conscien-tiousness & Courtesy & $\begin{array}{l}\text { Sports- } \\
\text { manship }\end{array}$ \\
\hline \multicolumn{6}{|c|}{ Organizational Culture $\left(\mathrm{X}_{1}\right)$} \\
\hline Clan Culture & 0.473 & 0.438 & 0.556 & 0.527 & 0.569 \\
\hline $\begin{array}{l}\text { Mission } \\
\text { Culture }\end{array}$ & 0.501 & 0.441 & 0.576 & 0.537 & 0.546 \\
\hline $\begin{array}{c}\text { Adaptability } \\
\text { Culture }\end{array}$ & 0.478 & 0.408 & 0.64 & 0.607 & 0.596 \\
\hline $\begin{array}{l}\text { Bureaucratic } \\
\text { Culture }\end{array}$ & 0.542 & 0.42 & 0.596 & 0.594 & 0.624 \\
\hline \multicolumn{6}{|c|}{ Organizational Justice $\left(\mathrm{X}_{2}\right)$} \\
\hline $\begin{array}{l}\text { Distributi } \\
\text { ve Justice }\end{array}$ & 0.472 & 0.421 & 0.557 & 0.598 & 0.549 \\
\hline $\begin{array}{l}\text { Procedura } \\
\text { 1 Justice }\end{array}$ & 0.451 & 0.376 & 0.526 & 0.517 & 0.429 \\
\hline $\begin{array}{l}\text { Interactio } \\
\text { nal Justice }\end{array}$ & 0.482 & 0.42 & 0.552 & 0.489 & 0.457 \\
\hline \multicolumn{6}{|c|}{ Organizational Commitment $\left(\mathrm{X}_{3}\right)$} \\
\hline $\begin{array}{c}\text { Affective } \\
\text { Commitment } \\
\end{array}$ & 0.403 & 0.402 & 0.525 & 0.587 & 0.567 \\
\hline $\begin{array}{c}\text { Continuati } \\
\text { on } \\
\text { Commitment }\end{array}$ & 0.319 & 0.332 & 0.463 & 0.513 & 0.603 \\
\hline $\begin{array}{r}\text { Normative } \\
\text { Commitment }\end{array}$ & 0.315 & 0.438 & 0.476 & 0.65 & 0.544 \\
\hline
\end{tabular}

In the organizational culture variable, the relationship between the adaptability culture dimension and the conscientiousness dimension of the OCB variable was the strongest. The weakest relationship occurred between the dimension of adaptability culture and the dimension of civic virtue. The strongest relationship between the dimensions of the organizational justice variable with the dimensions of the OCB occurred between the distributive justice dimension and the courtesy dimension. Meanwhile, the weakest relationship occurred between the dimensions of procedural justice and civic virtue. Between the dimensions of the organizational commitment variable and the OCB variable dimensions, the strongest relationship was in the normative commitment dimension with the courtesy dimension while the weakest relationship occurred between the normative commitment dimension and the altruism dimension.

\section{DISCUSSION}

The results showed organizational culture had a positive and significant effect on organizational citizenship behavior of employees. Thus, the first hypothesis was supported by the results of this study. The results of this study were consistent with the researches conducted by Eromafuru (2020), Arumi M. S, et. al (2019), Laihad G.H, et. al (2016), and Ghashghaeinia \& Hafezi (2015). Based on the analysis between dimensions, the strongest relationship was in the relationship between the dimension of adaptability culture and the dimension of conscientiousness. Therefore if employees had the opportunity to innovate and dare to take risks in their work, it would increase aspects of the sense of responsibility and discipline of employees to do work and try to exceed what the school expects. The second hypothesis, organizational justice, had a positive and significant effect on employee organizational citizenship behavior. The results of this study were in line with the research proposed by Ali N. (2016), Ismail S., et al. (2018), Bazgir A., et al. (2018), and Khalifa \& Awad (2018). The strongest relationship was in the relationship between the dimension of distributive justice and the dimension of courtesy. Thus, if employees (2015) and Luly (2016).

(C) Copyright: All rights reserved. following the contributions, it would improve aspects of good relations between colleagues and avoid interpersonal problems. The third hypothesis, organizational commitment had a positive and significant effect on organizational citizenship behavior of employees. The results of this study were consistent with the research conducted by Fakhredin Taghinezhad et al. (2015), Khan S.K. \& Rashid M.Z.A (2015), and Nugraha I. P. S \& Adnyani (2018). The analysis between the dimensions showed that the strongest relationship was in the relationship between the normative commitment dimension and the courtesy dimension. So if employees felt that school was a better place to work than other places, the school had contributed to their life, and pleasant work experience would increase aspects of good relations between colleagues and avoid interpersonal problems. The results also showed that organizational culture, organizational justice, and organizational commitment simultaneously had a positive and significant effect on employee organizational citizenship behavior. Thus, the hypothesis was supported by the results of this study. The results of this study were in agreement with the research conducted by Sari Maysarah \& Mudji Rahardjo

\section{CONCLUSION AND SUGGESTION}

This research on employee OCB at a private vocational school shows that organizational culture, organizational justice, and organizational commitment have a positive and significant effect on OCB either partially or simultaneously. This positive and significant influence means that if the organizational culture, organizational justice, and organizational commitment run well or increase, the employee's OCB will also be good or increase and vice versa. These results will be useful for school management to foster employee OCB through a school culture that provides space for employees to take initiative, be creative, and dare to take risks in their work to be able to develop new ideas or new strategies that lead to a sense of responsibility for the sustainability of school life and improving the quality of the field of work. In terms of organizational justice, schools need to continue to maintain procedures that are following applicable ethics and morals and are implemented consistently by increasing employee involvement in the decision or policymaking process so that employees feel treated fairly. In the case of social security provided by schools, the increase can lead to a high attitude of initiative and employee participation in the dynamics of school life. A harmonious social relationship between leaders and employees as well as between employees, will provide a pleasant atmosphere and work experience so that it can lead to loyalty among employees. For further research, other variables that influence OCB can be used, such as work motivation, work climate, job satisfaction, and others.

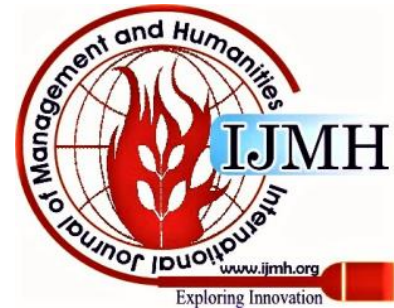




\section{REFERENCES}

1. Ali N. (2016). Effect of Organizational Justice on Organizational Citizenship Behavior: A Study of Health Sector of Pakistan. Review of Public Administration and Management, 4(3), 1 - 9.

2. Arumi, M. S., Aldrin, N., \& Murti, T. R. (2019). Effect of Organizational Culture on Organizational Citizenship Behavior with Organizational Commitment as a Mediator. International Journal of Research in Business and Social Science, 8(4), 124-132.

3. Awang, R. \& Ahmad, W. M. R. W. (2015). The Impact of Organizational Justice on Organizational Citizenship Behavior in Malaysian Higher Education. Mediterranean Journal of Social Science, 6(5), $673-678$.

4. Bakti, W. S. \& Riyanto, S (2020). The Influence of Work Environment, Organizational Culture, and Employee Development Against the Employee Capabilities on Employees of PT Petrosea Tbk. International Jurnal of Innovative Science and Research Technology, 5(1), $1110-1118$.

5. Batugal, M. L. C. \& Tindowen, D. J. C. (2019). Influence of organizational Culture on Teachers' Organizational Commitment and Job Satisfaction: The Case of Catholic Higher Education Institution in the Philippines. Universal Journal of Educational Research, 8(11), 2432 - 2443.

6. Bazgir, A., Vahdati, H., \& Nejad, S. H. M. (2018). A Study on the Effect of Organizational Justice and Commitment on the Organizational Citizenship Behaviors. International Journal of Administrative Science and Organization, 25(1), 8-15.

7. Cheasaku, U. \& Varma, P. (2016). The Influence of Passion and Empowerment on Organizational Citizenship Behavior of Teachers Mediated by Organizational Commitment. Contaduríay Administración, 61, 422-440.

8. Chib, S. (2016). Study on Organizational Commitment and Workplace Empowerment as Predictors of Organization Citizenship Behavior. Scholedge International Journal of Management \& Development, 03(03), 63 - 73.

9. Daft, R.L. (2010). Understanding the Theory and Design of Organizations. Cengage Learning International Offices. The United States.

10. Darius \& Wojtczuk, A. (2015). HRM Practices Influence Organizational Citizenship Behavior? Mediating The Role of Person-Organizational Fit. Technology, Innovation, and Industrial Management.

11. Demirel, Y., Elhusadi, I., \& Alhasadi, A. (2018). The Relationship between Organizational Citizenship Behavior and Organizational Factors. International Journal of Business and Management Invention (IJBMI), 7(3), 27-39.

12. Desselle, S. P., Raja, L., Andrews, B., \& Lui, J. (2018). Perceptions of Organizational Culture and Organizational Citizenship by Faculty in U.S Colleges and School of Pharmacy. Journal of Current in Pharmacy Teaching and Learning on Science Direct, 10, 403-412.

13. Eromafuru, Edward, Godbelss, Aigbomian, \& Ewan, S. (2020) Focusing Organizational Culture and Employees' Citizenship Behavior Narratives on Broadcasting Organization in Nigeria. Asian Journal of Social Sciences and Management Studies, 7(1), 71 - 79.

14. Ghashghaeinia, A. R. \& Hafezi, S. (2015). Relationship between Organizational Culture and Organizational Citizenship Behavior among Personnel of Islamic Azad University of Fars. J. Appl. Environ. Biol. Sci., 5(11), 131-138.

15. Greenberg, J. (2011). Behavior in Organizations. Pearson Education. England.

16. Imamoglu, S. Z., Ince, H., Turkcan, H., \& Atakay, B. (2019). The Effect of Organizational Justice and Organizational Commitment on Knowledge Sharing and Firm Performance. 3rdWorld Conference on Science, 899 - 906 .

17. Indahjati, N. \& Sintaasih, D. K. (2019). The Relationship between Organizational Justice with Job Satisfaction and Organizational Citizenship Behavior. International Research Journal of Management, IT \& Social Sciences, 6(2), 63-71.

18. Ismail, S., Iqbal, Z., \& Adeel, M. (2018). Impact of Organizational Justice and Organizational Citizenship Behavior on Employees Performance. International Journal of Human Resource Studies, 8(2), 187-200.

19. Junru X. (2019). The Influence of Teacher's Perceived Organizational Justice on Organizational Citizenship Behavior in Chinese Private Universities: Mediate Role of Job Satisfaction. The International Journal of Organizational Innovation, 12(1), 295 - 303. Technology, Innovation, and Entrepreneurship, Procedia Computer

20. Khaleh, L. A. B. C. \& Naji, S. (2016). The Relationship between Organizational Commitment Components and Organizational Citizenship Behavior in Nursing Staff. International Journal of Medical Research \& Health Sciences, 5(5), 173-179.

21. Khalifa, S. M. A. \& Awad, N. H. A. (2018). The Relationship Between Organizational Justice and Citizenship Behavior As Perceived By Medical-Surgical Care Nurses. IOSR Journal of Nursing and Health Science, 7(4), 31 - 37.

22. Khan, S. K. \& Rashid, M. Z. A. (2015). The Mediating Effect of Organization Commitment in the Organization Culture, Leadership, and Organization Justice Relationship with Organization Citizenship Behaviour: A study of Academics in Private Higher Learning Institutions in Malaysia. International Journal of Recent Advances in Organizational Behaviour and Decision Sciences (IJRAOB), 1(2), $335-359$.

23. Kittikunchotiwut, P. (2017). The Effect of Organizational Justice on Organizational Citizenship Behavior. Review of Integrative Business and Economics Research, 6(3), 116 - 130.

24. Kumari, .P \& Thapliyal, S. (2017). Studying the Impact of Organizational Citizenship Behavior on Organizational Effectiveness. International Academic Journal of Organizational Behavior and Human Resource Management, 4(1), 9-21.

25. Laihad, G. H., Sujanto, B., \& Putrawan, I. M. (2016). Enhancing Organizational Citizenship Behavior of Teachers in Pre-School. International Journal of Managerial Studies and Research, 4(3), 25 28

26. Luly, C. S. (2016). Analisis Pengaruh Budaya Organisasi dan Keadilan Organisasi Terhadap Organizational Citizenship Behavior dengan Komitmen Organisasi Sebagai Variabel Intervening. Jurnal Riset Bisnis dan Manajemen, 4(3), 277-288.

27. Maska, H. \& Riyanto, S (2020). The Influence of Job Embeddedness, Salary, and Organizational Commitment against the Turnover Intention of the Employees in the Marketing Division at Pharmaceutical Laboratories Industry in Jabodetabek. IOSR Journal of Business and Management, 22(2), 29-35.

28. Maysarah, S. \& Rahardjo, M. (2015). Analisis Pengaruh Budaya Organisasi, Keadilan Organisasi, dan Komitmen Organisasi terhadap OCB (Studi Pada PT Kereta Api Indonesia (Persero) Daerah Operasi 4 Semarang). Jurnal Manajemen Universitas Diponegoro, 4(4), 1-14

29. Musringudin, Akbar, M., \& Karnati, N. (2017). The Effect of Organizational Justice, Job Satisfaction, and Organizational Commitment on Organizational Citizenship Behavior (OCB) of the Principles. Indonesian Journal of Education Review, 4(2), 155 - 165.

30. Naiemah, S. U., Aris, A. Z. Z., \& Karim, K. M. (2017). Relationships between Organizational Commitment, OCB, Organizational Justice, and Turnover Intention: Evidence from Educational Institution in Malaysia. Review of Integrative Business and Economics Research, 6(2), $64-77$

31. Nawangsari, L. C. \& Prasetya, R. Y. (2019). The Influence of Leadership Style, Organizational Culture, and Work Motivation on Organizational Citizenship Behavior for Environment (OCBE) of the Directorate General of Fiscal Balance's Employees. International Jurnal of Innovative Science and Research Technology, 4(12), 641 647.

32. Nawangsari, L. C. \& Sutawidjaya, A. H. (2018). The Impact of Human Resources Practices Affecting Organization Citizenship Behavior with Mediating Job Satisfaction in University. Advanced in Social Science, Education, and Humanities Research, 200

33. Nugraha, I. P. S. \& Adnyani, I. G. A. D. (2018). Pengaruh Budaya Organisasi, Komitmen Organisasi dan Kompetensi terhadap Organizational Citizenship Behavior pada Setda Kota Denpasar. E-Jurnal Manajemen Unud, 7(1), 1-28.

34. Pan, X., Chen, M., Hao, Z., \& Bi, W. (2019). The Effects of Organizational Justice on Positive Organizational Behavior: Evidence from a Large-Sample Survey and a Situational. Frontiers in Psychology, 8(2315), 1-16.

35. Puspitasari, S. O. \& Riyanto, S.(2020). The Influences of Transformational Leadership and Training on Succession Management as Mediation Variables in Effort to Increase an Organizational Capability at PT Gama Plantation. International Journal of Innovative Science and Research Technology, 5(1), 1119 1128.

Published By:

Blue Eyes Intelligence Engineering

\& Sciences Publication

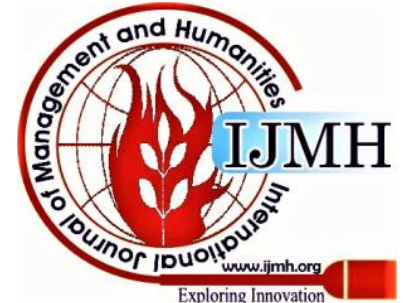


The Effect of Organizational Culture, Organizational Justice, and Organizational Commitment on Organizational Citizenship Behavior (OCB)

36. Robbins, S. P. \& Judge, T. A. (2017). Perilaku Organisasi. Salemba Empat. Jakarta.

37. Sani, A. \& Soetjipto, B. E. (2016). Organizational Justice and The Role of Organizational Commitment in Mediating the Effect of Job Satisfaction on Intention to Leave (A Study at Bank Syariah Mandiri in Malang). Indonesian Journal Education Research, 13(2), 587 601.

38. Setyaningrum, R. P. (2017). Relationship between Servant Leadership in Organizational Culture, Organizational Commitment, Organizational Citizenship Behavior, and Customer Satisfaction. European Research Studies Journal, XX(3A), $554-569$.

39. Taghinezhad, F., Safavi, M., Raiesifar, A., \& Yahyavi, S. H. (2015). Antecedents of Organizational Citizenship Behavior among Iranian Nurses: A Multicenter Study, BMC Research Notes, 8(547), 1-8.

40. Tran, T. B. H. \& Choi, S. B. (2019). Effects of Inclusive Leadership on Organizational Citizenship Behavior: the Mediating Roles of Organizational Justice and Learning Culture. Journal of Pacific Rim Psychology, 13(17), 1 -11.

41. Veličkovska, I. (2017). Organizational Citizenship Behavior-Definition, Determinants, and Effects.

42. Journal Engineering Management, 3(1), 40 - 51

43. Yean, T. F. \& Yusof, A. A. (2015). Organizational Justice: A Conceptual Discussion. in 3rd Global Conference on Business and Social Science, Procedia Social and Behavioral Science 219, Kualalumpur, Malaysia, 798-803.

\section{AUTHORS PROFILE}

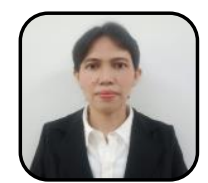

Sri Winarsih, Post Graduate Student, Universitas Mercu Buana, Jakarta, Indonesia. Email: wienarsih27@gmail.com.

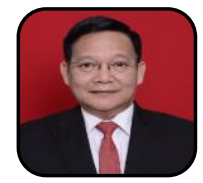

Setyo Riyanto, Post Graduate Lecturer, Universitas Mercu Buana, Jakarta, Indonesia. Email: setyo.riyanto@mercubuana.ac.id

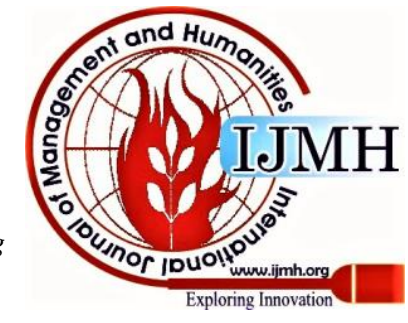

